Review

\title{
Sustainable Forest Management for Nontimber Products
}

\author{
James Chamberlain ${ }^{1, *}$, Christine Small ${ }^{2}$ and Michelle Baumflek ${ }^{3}$ \\ 1 U.S. Forest Service, Southern Research Station, 1710 Research Center Drive, Blacksburg, VA 24060, USA \\ 2 Department of Biology, Radford University, Radford, VA 24142, USA; cjsmall@radford.edu \\ 3 U.S. Forest Service, Southern Research Station, 200 W.T. Weaver Blvd., Asheville, NC 28804, USA; \\ michelle.baumflek@usda.gov \\ * Correspondence: james.l.chamberlain@usda.gov; Tel.: +1-540-231-3611
}

Received: 9 April 2019; Accepted: 4 May 2019; Published: 10 May 2019

check for updates

\begin{abstract}
Many of the plants and fungi that are harvested for nontimber products (e.g., foods, medicines, crafts) are critical to healthy forest ecosystems. These products also are essential to rural societies, contributing to the material and nonmaterial composition of communities and cultures. Product sales make important contributions at all economic scales, from household to national economies. Nontimber forest products (NTFPs) have been harvested for generations, sometimes centuries, yet they are seldom integrated into forest management. Few methods exist for inventory and assessment, and there is little evidence that harvests are sustainable. This article examines three elements of sustainable forest management for nontimber products: sociocultural, economic, and ecological, and elaborates with detailed examples of edible and medicinal species from United States (U.S.) forests. We synthesize the state of knowledge and emerging issues, and identify research priorities that are needed to advance sustainable management of NTFPs in the United States. Despite their social, economic, and ecological values, many of these species and resources are threatened by the overuse and lack of management and market integration. Sustainable management for nontimber products is attainable, but much research and development is needed to ensure the long-term sustainability of these resources and their cultural values, and to realize their economic potentials.
\end{abstract}

Keywords: Actaea racemosa; Allium tricoccum; edible plants; forest inventory; local and traditional ecological knowledge; medicinal herbs; Panax quinquefolius; understory herbaceous layer; wild-harvesting

\section{Introduction}

Many forest products are not derived from trees, nor do they require trees to be of industrial scale use. In fact, forests are sources of more types of plant-based products (e.g., food, medicine, arts and crafts, floral decoratives) than just timber, and they may be sustainably managed for both nontimber and timber products [1]. The harvest of nontimber forest products for commerce in the United States significantly contributes to the national, state, and household economies. In 2013, the estimated national wholesale value of NTFPs was approximately US\$1 billion [2]. It is arguably a low estimate, as this estimate is based on issuances of permits harvesting from public forests, and it does not include the value of products harvested from private lands. A comprehensive valuation assessment of the NTFP industry is lacking, but evidence from individual products suggest that the value is substantial. This, coupled with the 'management' of most NTFPs as open access resources [3], has major implications for the production, regulations, and exploitation and decline of natural populations [4].

NTFPs also contribute to the culture and social fabric of people and communities around the world [5]. These products are central to the traditions, livelihood, and overall wellbeing of indigenous 
and minority communities. Immigrant harvesters bring with them knowledge regarding NTFPs from their homelands and integrate that understanding into their current practices. Some NTFPs are so important to certain groups of people that they are considered to be cultural keystone species; their loss would be a severe risk to aspects of cultural identity [5]. Over generations of sharing experiences, indigenous and immigrant communities have gained much knowledge regarding NTFP plants and fungi. This traditional and local knowledge may provide valuable information toward sustainable management.

NTFPs are derived from a wide range of plants and fungi and from all layers of forest ecosystems [6,7]. Due to these products being integral to forest health and resilience [8-10], uncontrolled harvesting can have significant negative impacts on species and ecosystems. Most wild harvest research suggests the potential for severe population declines in medicinal and edible forest herbs (e.g., [11-14]), although specific impacts and potential for sustainable use appear to be strongly linked to species life histories and the biological components used [1,15]. This growing body of knowledge emphasizes the importance of expanded research and monitoring to achieve sustainable use.

Sustainable forest management of NTFPs and long-term viability of the species will require an improved understanding of harvest methods, quantities, and product values, and associated biological responses $[15,16]$. Silvicultural practices, which were developed through a long history of timber management and scientific analysis, experiences of harvesters, and traditional and local ecological knowledge can provide valuable foundations and insights in sustainability. We review important sociocultural, economic, and ecological dimensions to consider long-term sustainable management and silvicultural practices that can lead to better integration of nontimber products into multiple use forest management systems. This review article is based on research by the authors and the synthesis of knowledge discovered in a national assessment of NTFPs in the United States.

\section{Sociocultural Sustainability}

\subsection{Overview}

Harvesting NTFPs for social and cultural reasons is widely-practiced and it provides many non-monetary benefits across economic and geographic spectrums. People of diverse ethnicities, incomes, ages, and genders gather NTFPs for food, medicine, artisanal materials, and cultural purposes [17]. The perspectives, actions, and knowledge of harvesters are important sociocultural considerations for sustainable management of nontimber forest products. Gathering occurs in rural, suburban, and urban environments, across public and private landownerships [18,19]. The most recent National Woodland Owners Survey (2011-2013) found that approximately $20 \%$ of nonindustrial private forest owners in the United States (U.S.) harvest NTFPs from their property [20]. However, access to NTFPs may be a challenge for harvesters who do not own land, particularly in parts of the country with limited public forest lands [21].

The collection and processing of NTFPs significantly contribute to livelihoods, wellbeing, and cultural identity. Many of these sociocutural benefits are amassed outside of formal market systems [17]. National surveys and finer-scale ethnographic research demonstrate that a large amount of NTFP harvesting in the U.S. is for personal consumption $[19,20,22]$. Harvesting wild plants and fungi contributes to health outcomes by providing opportunities for physical exercise and access to nutritious foods and medicines. Social connections to family and community members are strengthened through harvesting, preparing, and exchanging knowledge regarding NTFPs. Gifting or sharing NTFPs is a common practice that further reinforces social ties [22]. NTFPs simultaneously contribute to cultural practices and continuity, and some are cultural keystone species that are integral in shaping the identity of groups of people [23]. In turn, the traditional and local knowledge that is gained from generations of harvesting NTFPs may support their sustainable management. 


\subsection{Traditional and Local Ecological Knowledge}

Traditional and local ecological knowledge are important considerations in the sustainable management of NTFPs. Gathering practices of many indigenous communities are informed by traditional ecological knowledge (TEK), defined as "a cumulative body of knowledge and beliefs, handed down through generations by cultural transmission, about the relationship of living beings (including humans) with one another and with their environment" [24]. TEK is dynamic, being based on observations and interactions with specific environments over time, and may provide adaptation strategies for changing the socioecological conditions [25]. Recent studies stress the importance of respectful community-guided collaboration, innovative institutional arrangements, and the benefit of sharing with indigenous groups regarding the co-production of knowledge around development of NTFPs [26].

Local ecological knowledge (LEK), defined as "local expertise of peoples that may not have a long-term relationship with the local environment, but nevertheless has local wisdom, experience and practices adapted to local ecosystems" [27], also can provide valuable insights for NTFP management. The value of LEK for sustainability has been documented for commercially harvested NTFPs, including salal (Gaultheria shallon Pursh.) and morel (Morchella spp.) mushrooms [27-29]. Practical, hands on knowledge contributes to NTFP sustainability through ethical harvesting practices and specific stewardship actions [17].

\subsection{Sociocultural Knowledge for Sustainable Management}

Some indigenous and local communities have developed stewardship systems that encourage culturally significant plants, based on an understanding of plant biology and responses to harvest [30]. These practices are rooted in values of respect, reciprocity, and giving thanks, and they are guided by ethics and cultural norms that regulate harvesting [31,32]. Practices such as these, based on sociocultural knowledge, may support the sustainable management of NTFPs.

Sociocultural practices to sustainably manage NTFPs based on traditional and local knowledge include rotating the gathering sites and regulating harvest intensity and frequency [17,33]. Minimizing stress and injury to plants by harvesting at appropriate times of year or at specific times in a plant's life cycle is also an important component of TEK. For example, branches of shrubs that are used for basketry, including willow (Salix spp.) and dogwood (Cornus spp.), are typically collected during the plant's dormant season, from late fall to early spring, to minimize the harvest impacts [33,34]. When harvesting roots, experienced harvesters may select plants of certain size classes, which leaves some mature and juvenile plants to restock the populations. Ethical harvesters scatter seeds or replant immature bulbs, corms, or pieces of rhizomes to promote future plant growth [33]. These and other gathering strategies are based on years of observation and hands-on interactions with the plants and their habitats. Many sociocultural practices have been corroborated by modern science, yet others need further study to verify their efficacy.

Certain practices that are grounded in TEK and LEK may enhance NTFP production and ecosystem functions [30,33,35-37]. Pruning or coppicing a moderate proportion of a plant's stems may stimulate the epicormic and adventitious buds, and they result in increased biomass production [33]. Similarly, selective thinning can encourage ramet regrowth in clonal plants, such as sweetgrass (Anthoxanthum nitens (Weber) Y. Schouten \& Veldkamp) [38]. The harvest of ramps (Allium tricoccum Ait.) is grounded in TEK and LEK. Today, these practices are being examined through scientific research to ascertain their effectiveness relative to sustainable management.

\subsection{Ramps: Integrating TEK for Sustainble Management}

Ramps, also known as wild leeks, are clonal edible onions native to the hardwood forests of eastern North America. Traditionally associated with the culture and economy of the Appalachian region [39], ramps have seen a dramatic increase in popularity as a seasonal delicacy since the 1980s [40]. Tens of 
thousands of pounds of ramps are harvested each year to support an expanding national market [41]. Although considered to be common across much of its range, three states assign legal conservation status to the species in response to concerns regarding overharvesting.

Ramps are spring ephemerals, slow-growing perennial wildflowers that depend on delayed forest canopy phenology and associated high understory light conditions for development and seed production [42,43]. The leaves emerge in early spring, with a photosynthetic period of less than three months. Vegetative propagation is the main source of population expansion [44], although they do sexually reproduce. These life-cycle traits are important considerations for sustainable management strategies.

Although the entire plant is edible, many people have traditionally preferred consuming only the bulbs. Conventional harvesting approaches that remove whole plants, including bulbs and rhizomes, negatively affect plant populations, unless done in limited quantities with long rotations [11,44]. Based on findings of a five-year ramet demography study, [44] predicted that the harvesting rates of approximately five percent to 15 percent could cause population decline. Rock et al. [11] observed population recovery after harvests of $0 \%, 25 \%, 50 \%, 75 \%$, and $100 \%$ for a minimum of four years, and proposed that sustainable harvest levels may be possible if the harvests were limited to approximately $10 \%$ of a population once every 10 years.

While simulated harvest studies have focused on methods that involve bulb removal, some Native American communities use different harvesting practices. Recently initiated research is examining the TEK of ramp harvesting by the Eastern Band of Cherokee Indians that involves cutting the petiole and leaving a portion of the bulb and rhizomes in the ground [45]. A leaf-only harvest has been found to not affect plant mortality [46] and it may be a more sustainable option when compared to harvests that involve total plant removal. Understanding the long-term impacts of different harvest techniques is essential in the sustainable management of this and other edible NTFPs, and the integration of local and traditional knowledge into research may advance sustainable management of these forest resources.

\section{Economic Sustainability}

\subsection{Overview}

The commercial harvest of NTFPs, including ramps, contributes to an industry with market segments that support culinary, medicinal, decorative, fine art, and other enterprises. The commercial harvest of NTFPs dates back to before the founding of the U.S.; one of the first exports (ca, 1600) from the New World to Europe was the roots of sassafras (Sassafras albidum (Nutt.) Nees) for medicinal tea [6]. The discovery of synthetic pharmaceutical materials that could be substituted for botanical remedies changed the market for medicinal plants, but they continued to be used, and, in recent years, there has been a resurgence of interest in medicinal forest products. With demand for foods that are foraged from forests for the culinary industry, we have seen associated increases in harvest pressures on populations of edible forest plants [45]. The lack of tracking and monitoring of NTFP harvests hinders any comprehensive assessments of the volumes and values, as well as any estimates of the number of harvesters that support the industry [2]. However, the limited knowledge available provides compelling evidence that large volumes, with significant values, are harvested for the industry, and that this industry supports millions of people.

Large volumes of NTFP biomass are extracted each year according to harvest permits issued by U.S. federal forest management agencies [2]. Under the product category "edible fruits, nuts, berries and sap", the U.S. Forest Service and Bureau of Land Management reported that permits were issued for the harvest of more than $304,000 \mathrm{~kg}$ and 1.1 million liters of edible products in 2013. Evaluating the five-year period from 2009 to 2013, these agencies reported 1.3 million $\mathrm{kg}$ and $\sim 3.5$ million liters of food being harvested from federal forestlands. The harvest of other nontimber product categories is also sizable. In 2013, these forest management agencies reported that more than 19,000 kg of plant materials were harvested for medicinal products, and over 2.5 million $\mathrm{kg}$ for arts, crafts, and floral 
products. As noted above, the lack of monitoring and measurement consistency limits our ability to estimate the total product volumes and harvest impacts.

The harvest of NTFPs significantly contributes to national, state, and household economies. For example, Alexander et al. [47] estimated the wholesale value of NTFPs in 2007 to be about US\$682 million, being adjusted to 2007 US dollars. Using the method developed by [47], Chamberlain et al. [2] estimated the wholesale of NTFPs in 2013 at approximately US $\$ 1$ billion. Albeit dated, in 1989, the value of the floral segment of the NTFP industry in the Pacific Northwest of the U.S. was approximately US $\$ 128.5$ million [48]. Using the prices paid to harvesters of saw palmetto (Serenoa repens (Bartram) J.K. Small) reported by [49], and the average annual harvests for 2001-2005 reported by [50], the estimated value of this medicinal plant in Florida exceeded US\$330,000 at the turn of the 21st century. In 2012, the harvest of pine straw (Pinus spp.) needles for mulch in the state of Georgia accounted for almost 10 percent of the forest products market [51]. In the same year, the estimated annual value of American ginseng (Panax quinquefolius L.) roots to the harvesters was more than US\$27 million [52]. These estimates indicate substantial values at all levels of the economy, although a comprehensive assessment is lacking.

Despite these values, most of the NTFPs are 'managed' as open access resources [3], which has major implications for markets and management [4]. Products can become 'de facto open-access" resources when access to them is difficult, if not impossible, to control and monitoring or limiting the harvests is not feasible [4]. The bioeconomic impacts on open access resources, such as fisheries and forests without management, have been documented, and they clearly reveal resources in ecological decline with concomitant economic implications. American ginseng provides a similar example of a product 'managed' as open access, with comparable ecologic and economic consequences.

\subsection{American Ginseng: Bioeconomics of an Open Access NTFP}

The commercial harvesting of American ginseng roots from eastern U.S. forests has impacted ecosystems and the economies of rural communities for over 250 years [52]. Ginseng is a long-lived and slow-growing forest perennial, harvested for the medicinal properties of its roots and rhizomes. By the early 1900s, there were concerns regarding the long-term sustainability of ginseng wild-harvest in Canada and the U.S. [53]. In 1975, the species was listed in Appendix II of the Convention on International Trade of Endangered Species of Wild Fauna and Flora (CITES), which regulates export and requires assurances that international trade will not be detrimental to the species existence. Nineteen U.S. states are certified to export ginseng roots and they have state-level management plans and policies that include harvest seasons and the reporting of annual harvest volumes [52].

Large volumes of ginseng roots have been harvested for commercial gain [52]. From the mid-18th century to the beginning of the 20th century, the U.S. exported over nine-million $\mathrm{kg}$ of American ginseng roots. From 2000-2013, the 19 states that were certified for export reported the harvest of more than 405 thousand $\mathrm{kg}$ of ginseng roots (Figure 1). The annual harvests ranged from 18.5 thousand $\mathrm{kg}$ in 2005 to 37.6 thousand $\mathrm{kg}$ in 2009. The geographic focus of American ginseng harvest is similar to that of many other medicinal and edible plants that were harvested for commercial gain, with about $70 \%$ of the total annual harvest of ginseng occurring in just seven eastern U.S. states (Figure 2). 


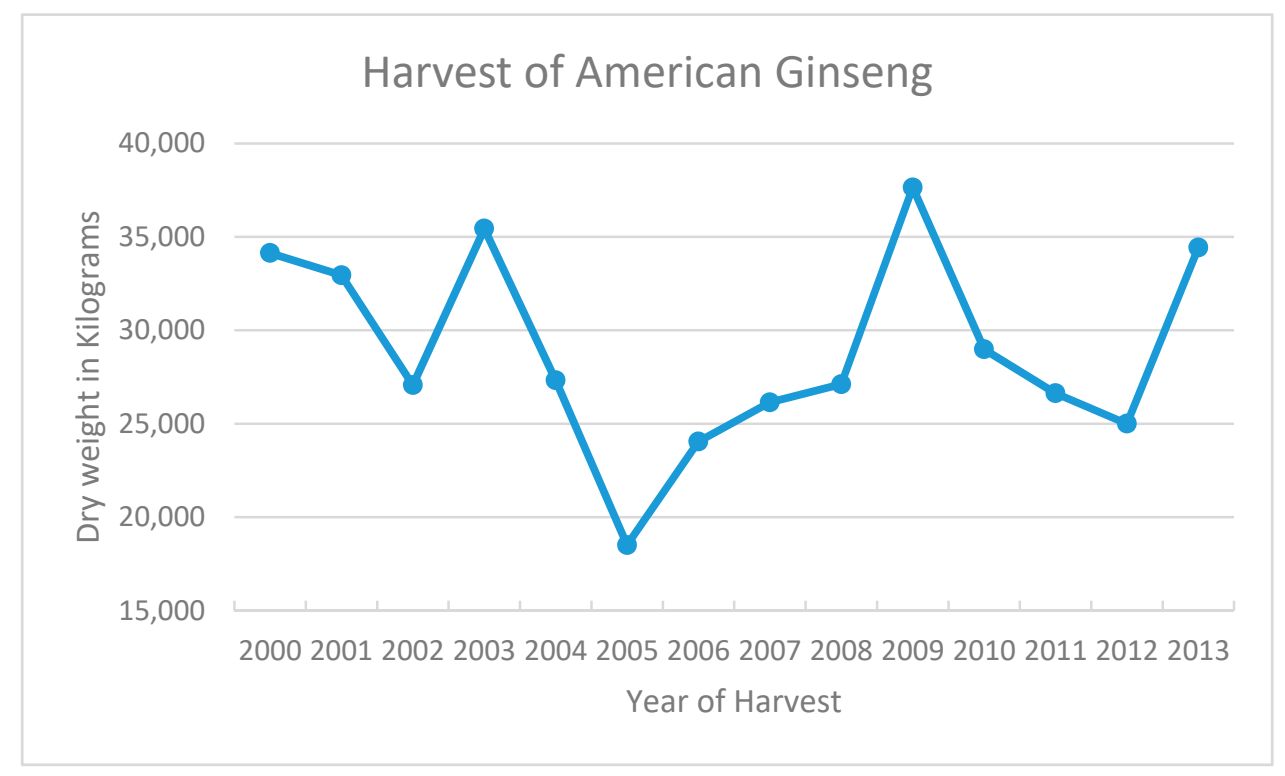

Figure 1. The annual harvest of American ginseng, reported in dry weight kilograms, fluctuated widely between 2000 and 2013, with less than 20,000 kg harvested in 2005, and more than 35,000 kg harvested in 2009. The long-term trend has been a declining harvest. Data source: US Fish and Wildlife Service.

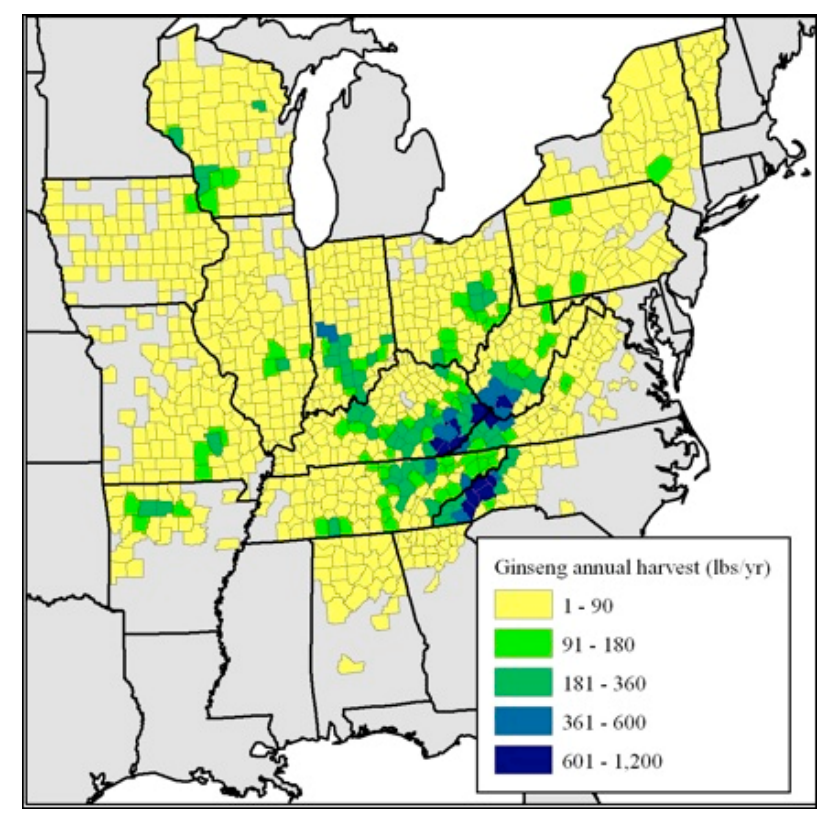

Figure 2. The majority of American ginseng is harvested in its core ecological range. The medicinal plant shares this biologically rich forest habitat with a vast diversity of native plants valued for their food and medicinal properties. Source: [1].

The forests from which American ginseng is harvested are some of the most biologically diverse forests in the temperate regions of the world. Ginseng shares these rich deciduous forest ecosystems with a vast array of other important plants, such as black cohosh (Actaea racemosa L.), ramps, and blue cohosh (Caulophyllum thalictroides (L.) Michx.). More than half of the 22 medicinal forest plants that were reported by the American Herbal Products Association grow in the same forest region, most notably in the Central and Southern Appalachian Mountains [1]. These forests, from which American ginseng has been harvested, have been managed for timber and other objectives for several hundred years. This forest management approach, as well as the natural stand dynamics, deer herbivory, and harvest practices have been shown to have significant impacts on the ginseng populations [14,54]. 
Chamberlain et al. [52] found that harvest volumes of American ginseng were greater in forests with more growing stock timber volume. As the volume of standing timber increased, there was an associated increase in harvest of ginseng. The relative growth rate of ginseng was also found to increase with timber harvest intensity, although survival decreased after timber harvesting [54]. Consecutive years of deer browsing have been shown to produce noticeable declines in ginseng relative growth rate and stem height [14]. Analyzing herbaria specimens from nearly 20 eastern U.S. states, [55] reported long-term declines in ginseng size and abundance over the past 150 years. Likewise, [56] found greater genetic diversity in ginseng populations that have been protected from harvest. McGraw et al. [14] contend that conservation of ginseng would improve if the forest structure resembled old growth. However, given sufficient habitat, recent studies suggest that socioeconomic conditions, such as employment, poverty level, and income are more critical drivers of harvest intensities [57]. These issues are likely to have similar influences on other valuable NTFPs, because, as revealed by [58], harvesters often are collecting more than ginseng.

With open access resources, like American ginseng, harvest location, timing, access, and the number of harvesters is typically unrestricted. This places natural populations at risk of overexploitation and decline [4,57]. According to [4], open access renewable natural resources may be imperiled by intense harvest pressures that limit the regeneration and lead to a supply curve that is the opposite of the economic Law of Supply, which states that the aggregate quantity supplied is positively related to prices. Two conditions are needed for such a supply curve: biological limitations on reproduction and inability to restrict access to harvest [59]. Such a backward bending long run supply curve is a phenomenon that is observed in fisheries and forestry with no investment in management [60-62].

Bioeconomic models of wild-harvested ginseng revealed a backward-bending long-run supply curve, which is consistent with other common-pool resources [4]. Frey et al. [4] provide empirical evidence that quantities of American ginseng supplied are negatively related to long-term price trends, which is an indication that harvest pressures are inhibiting ginseng populations from recuperating from harvest. The results indicate that harvest pressures are restricting inventories, a sign of over-exploited resources. Policies and regulations have been implemented for almost two decades to control the harvest and export of ginseng. Contrary to expectations, supply of ginseng has decreased (rather than stabilizing or increasing) in the 14 years that policies have been in place restricting harvest to plants five years or older. A possible explanation is that ginseng populations may take longer than 14 years to equilibrate to new, higher long-run equilibrium. Nonetheless, the long-run supply curve of American ginseng currently expresses a natural resource in decline. This analysis indicates that the supply of this iconic medicinal forest product has declined, and it suggests the that negative effects of open access are likely for other NTFPs.

\section{Ecological Sustainability}

\subsection{Overview}

Worldwide, many thousands of wild plant species are used for NTFPs, including subsistence needs $[7,63]$. The deciduous forests of eastern North America, particularly in the Appalachian Mountains, are an especially rich source of products, with hundreds of plant and fungal species being harvested for medicinal, edible, decorative, and cultural values [64,65]. Mosses, lichens, and fruiting bodies of mushrooms are harvested from the forest floor, and grasses, forbs, and ferns are harvested from the herbaceous layer. Additional products are derived from shrub or overstory canopy layers, including leaves, fruits, and bark of saplings, shrubs, vines, and trees [6,7].

Species that are used as NTFPs contribute to the structural, compositional, and functional diversity of forests, and to ecosystem-level processes. Many are herbaceous layer species, a vegetation layer that comprises the largest component of deciduous forest diversity and serves as an important indicator or control on site quality and ecosystem integrity $[9,66]$. For example, forest herbs that are used for food and medicine, such as ramps or wild leeks, blue cohosh, and wild sarsaparilla (Aralia nudicaulis L.) 
significantly contribute to seasonal nutrient dynamics, because of their rapidly decomposing plant tissues and high leaf nutrient concentrations. Early spring herbs, like ramps, also play important roles in controlling nutrient losses from forest soils during spring runoff [8]. Many species also provide food and habitat for pollinators and other wildlife [10].

\subsection{Importance of Biological Components for Sustainable Management}

The potential for sustainable harvest of NTFPs depends, in large part, on the part of the plant or the biological component used. The reproductive plant parts are widely harvested, most often as food products. These include fruits, like blueberries (Vaccinium spp.), pawpaw (Asimina triloba (L.) Dunal), and persimmon (Diospyros virginiana L.); seeds, such as walnuts (Juglans nigra L.) and pine nuts; and, the fruiting bodies of mushrooms, like morels, and chanterelles (Cantharellus spp.) [6,67]. Vegetative components are also important. Whole plants are harvested for gardens and landscaping, such as rhododendrons, wild azaleas (Rhododendron spp.), and mountain laurels (Kalmia latifolia L.). Others, like clubmoss (Lycopodium spp.) and Spanish moss (Tillandsia usneoides (L.) L.), are used in crafts and decorations [7]. Leaves are used for food and flavoring (e.g., ostrich fern (Matteuccia struthiopteris (L.) Todaro)), sassafras); medicines (e.g., wormwood (Artemisia vulgaris L.); and, decoration or crafts (e.g., galax (Galax urceolata (Poir.) Brummitt), palmetto). Bark is used for a variety of purposes, including food (e.g., Scots pine (Pinus sylvestris L.)); medicine (e.g., slippery elm (Ulmus rubra Muhl.), willow (Salix alba L.), witch hazel (Hamamelis virginiana L.)); and, aromatic, decorative, building, and other functional products (e.g., paper birch (Betula papyrifera Marsh.), tulip poplar (Liriodendron tulipifera L.), and cork oak (Quercus suber L.)) [7,67].

The use of such a broad range of biological components creates challenges for sustainable management. The potential harvest impacts are largely dependent on plant life history traits and the plant part harvested [15]. For example, hundreds of species of perennial herbs and fungi are harvested from eastern deciduous forests for food and medicine. Many, such as American ginseng, goldenseal (Hydrastis canadensis L.), ramps, and black cohosh, are harvested for below-ground organs (e.g., roots, rhizomes, corms) or entire plants [7]. Removing roots or adult plants reduces or entirely eliminates asexual reproduction and sexually reproductive individuals. Given the slow growth, specialized germination mechanisms, and reliance on clonal expansion in many of these species [68], the harvested populations often require many years to decades to recover $[14,69,70]$. It is important to note that viable sections of roots and rhizomes that remain after harvest may contribute to population regeneration, although more research is needed regarding the effects of harvest method and propagule size and quality for optimal recovery $[70,71]$.

Like belowground organs, plants that are harvested for bark are especially difficult to manage. The removal of bark, roots, or entire plants often causes severe damage or direct mortality, and it has been linked to shifts in population age structure (e.g., declines in reproductively mature individuals), loss of genetic diversity, and overall population decline [15,72]. As a general rule, species that are characterized by slow growth, infrequent or irregular reproduction, specialized germination or dispersal mechanisms, or restricted distributions tend to be most susceptible to harvest impacts [15,73]. In contrast, the collection of deciduous leaves or fruit, seeds, or other reproductive components, particularly from long-lived species (e.g., trees, shrubs, perennial herbs), tends to have relatively little impact on populations [15]. Thus, species that grow fairly quickly and have high rates of sexual or asexual reproduction and their generalist dispersal mechanisms usually recover more quickly from disturbance (including harvesting) and they have greater potential for sustainable use [15,67]. However, it should be noted that over-harvesting can negatively impact any species, regardless of the growth form or life history traits. For example, the harvest of edible fronds of ostrich fern from northeastern forests may be sustainable, in moderation, but excessive harvest reduces the photosynthesis and nutrients that are needed for growth, leading to decreased frond size and population vigor over time [74,75]. 


\subsection{Black Cohosh: Ecology and Sustainable Management of a Medicinal Forest Herb}

The linkages between NTFP harvest and sustainable forest management are evidenced by black cohosh, one of many native Appalachian forest herbs that are harvested for commercial value. The roots and rhizomes are collected for the global herbal and dietary supplement markets, primarily as a treatment for menopausal symptoms [76]. Like American ginseng and many other NTFPs that are valued for below-ground components, black cohosh appears to be particularly vulnerable to harvest impacts. Since 2002, this species has been listed by The American Herbal Products Association as a top 10 selling herbal supplement [50]. Nearly all of the black cohosh sold is harvested from natural populations $[76,77]$, and most forests are not managed for this medicinal plant (i.e., are defacto common pool resources). Declines of $10 \%$ to $30 \%$ are predicted across the natural range of black cohosh, unless the harvest pressures are reduced through cultivation or management [77,78]. In addition, a vulnerability assessment of North American medicinal herbs rated harvest impacts on black cohosh as especially high, due to the collection of its roots and rhizomes [73].

Experimental harvest studies clearly demonstrate that black cohosh is sensitive to harvest impacts [13,70]. Studies that were over a 14-year period (2005-2018) in Appalachian oak forests have helped to identify harvest intensities and frequencies that are likely to be sustainable for black cohosh in this region. After three consecutive years of experimental harvest, above-ground growth measures (e.g., leaf area, height, stem density) declined markedly (65\% to 90\% lower than unharvested controls), with impacts persisting for extended periods (Figure 3). Modeled data suggest that four to seven years without harvest were needed for above-ground growth to return to pre-harvest levels [70]. However, the field monitoring of these populations, after six to 10 years of post-harvest "recovery" (no additional harvests), showed the persistent lack of above-ground growth in all of the harvested populations. Repeated removal of one-third of the population (33\% harvest) over a three-year period resulted in significantly lower leaf area, plant height, and stem density (Figure 3). More concerning, stem density continued to decline, despite the cessation of harvest, indicating little or no new recruitment. This lack of seedlings and juvenile plants in post-harvest populations generates concern regarding long-term population persistence and regeneration, although long-term studies suggest that sustainable harvests may be possible by limiting the harvest intensity or frequency [13,70].

Methods are needed to manage harvests and to mitigate harvest impacts in natural populations of black cohosh and other root-based NTFPs. For long-lived forest herbs, like black cohosh, ginseng, goldenseal, and many others, above- and below-ground structures are critical in plant growth and expansion into new environments [68]. However, there are few methods to inventory any available product (e.g., estimate biomass of below-ground roots and rhizomes) without destructive harvesting. Although above-ground measures can be used to assess changes in population growth and recovery, relationships between above- and below-ground biomass are poorly understood [79-81]. Chamberlain et al. [80] used data from long-term sustainable harvest studies to develop and validate a predictive model for rhizome biomass in Appalachian black cohosh populations. The results demonstrated that an effective predictive model for harvestable below-ground biomass can be constructed while using above-ground metrics, such as leaf area and plant height, and they may serve as a template for developing inventory methods for the assessing sustainable use of other wild-harvested root-based products.

Forest farming is another approach to facilitate sustainable management of NTFPs. Forest farming, or "the cultivation of crops under a forest canopy that is intentionally modified or maintained to provide shade levels and habitat that favor growth and enhanced production levels" [82], can support sustainable management by reducing the wild-harvest pressures and increasing product availability through cultivation. In general, forest farming manages the understory forest crops in an established or developing forest, while 'wild-simulated' forest farming attempts to mimic the ecological structure of a natural ecosystem [83]. Simultaneously, forest farming aims to increase crop yields by incorporating agricultural productivity methods under a forest canopy [84]. Wild-simulated forest farming may be less productive than woods-grown forest farming (i.e., in which forest stands are extensively 
managed) methods, but it produces high-quality products that appear to be similar to wild-harvested plants [85]. In some product markets, such as American ginseng, this natural appearance is particularly important [83].
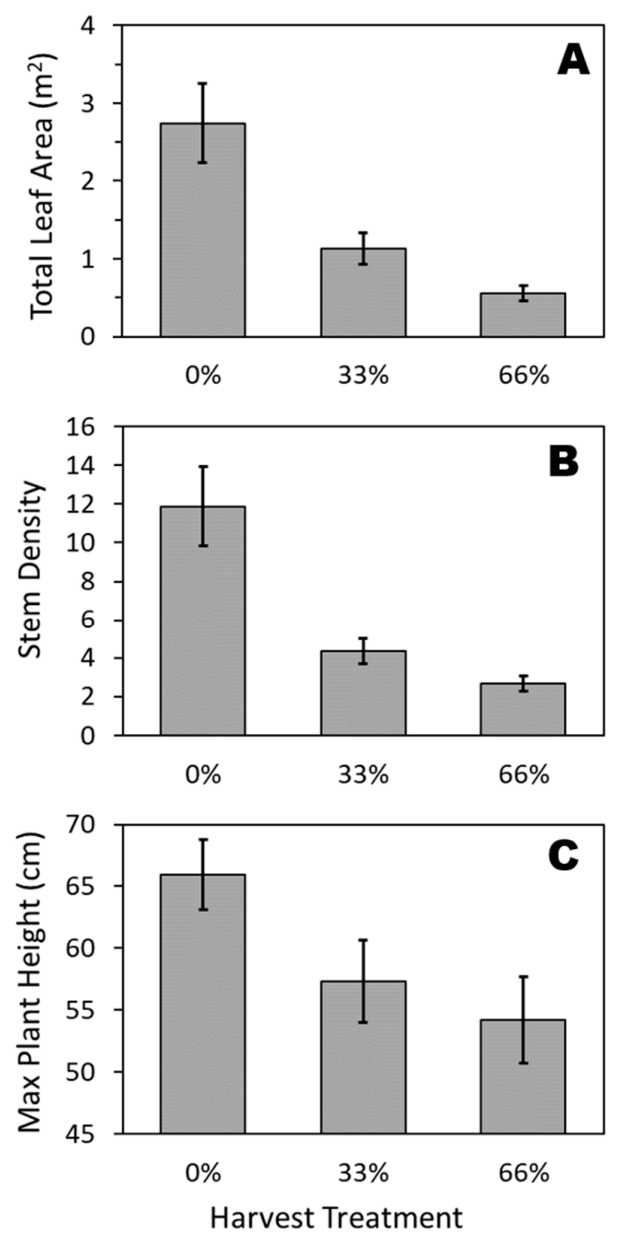

Figure 3. Response of Appalachian black cohosh populations to experimental harvest $(0 \%=$ no harvest; $33 \%=$ one-third population removal; $66 \%=$ two-thirds removal). Harvests were conducted for three consecutive years, followed by six to 10 years of post-harvest "recovery" (no additional harvests), in 109 permanent $2 \times 5 \mathrm{~m}$ plots. See [70] for experimental design.

Small et al. [81] used a wild-simulated forest farming approach to examine the growth requirements of black cohosh, while using 200 rhizomes transplanted from naturally occurring populations to similar forest systems. After two years of tracking growth and survival, they found that less than $40 \%$ of rhizomes produced above-ground growth and rhizome biomass had declined by more than $50 \%$. Transplant failure was linked to fungal infection and the quality of initial transplants. The results emphasized the importance of propagation sites and transplant methods, as well as the need for a better understanding of species requirements for forest farming to be successful in reducing the wild harvest pressures $[81,86]$.

\section{Sustainable Forest Management for Nontimber Products}

\subsection{Overview}

In general, forests of the U.S. are managed for multiple objectives, including timber, wildlife, water, and recreation. The concept of managing forests for several objectives is well accepted, yet nontimber products are seldom included as a specific management objective. Integrating NTFPs into 
forest management would enhance the sustainability of these products, but it would require a balance between the ecological and economic scales, as well as cultural and social needs $[1,87,88]$. Silvicultural techniques that were developed for timber can be incorporated to improve management of nontimber products. Although this may increase the complexity of management, it can improve forest utility, health, and resilience [89].

The knowledge that is needed for sustainable management of nontimber forest products is similar to that for timber, though far less developed. The basic information needed for NTFPs are estimates of what is going into the resource (i.e., reproduction and growth) and approximations of what is leaving the resource (i.e., harvest and mortality) [90]. In other words, population growth must exceed the population drain. For long-term sustainability, the inputs must equate or exceed the outputs, unless some other remediation or regeneration strategies are used, such as enhancement planting. A starting inventory of harvestable stock provides baseline information regarding the product of interest and it establishes the foundation for harvest management. An estimation of reproduction, and/or new cohorts, allows for a projection of population changes and the determination of age class distribution of the population. The mean annual incremental growth of the product provides information on how much biomass is being produced each year. With this information, we can estimate a beginning inventory, describe the population distribution, and estimate the annual changes in product biomass.

The outputs needed for sustainable management are harvest quantity and incremental decline of biomass. The average biomass that is harvested each year must be known for the population of interest. Knowledge also is needed about the average biomass that is lost to mortality or associated with growth or natural decline (e.g., sloughing of root mass) each year. Output information can then be compared to inputs to determine whether the resource is being sustainably managed. This equation for sustainable management of nontimber forest products, although simplistic, is challenging or impossible to implement (at this time), because all elements of the process have not been documented. Further, adequate time is needed for populations to recover from disturbances and harvests. The science-based knowledge that is needed for sustainable forest management of NTFPs is lacking, and this void may be improved by integrating TEK and LEK in research, development, and management.

\subsection{Integrating Traditional and Local Ecological Knowledge}

Sustainable management goals may be enhanced by incorporating the needs, cultural values, and knowledge of indigenous communities [91,92]. Certain communities may prefer forest planning approaches that prioritize culturally significant NTFPs over timber. For instance, the Mescalero Apache tribe aims to actively manage their tribal forestland for the availability of Douglas fir teepee poles (Pseudotsuga menziesii (Mirb.) Franco) and other cultural uses [93]). Other tribes, including the Karuk Tribe of California and the Eastern Band of Cherokee Indians, have forest resource management plans that include objectives to promote the availability of traditional foods and artisanal materials [94,95].

Traditional ecological knowledge can inform management approaches by highlighting the optimal growing conditions or the preferred traits for specific NTFP species. Hummel and Lake [96] found that Native American basketmakers in the Pacific Northwest preferred harvest sites for beargrass (Xerophyllum tenax (Pursh) Nutt.) that were characterized by large diameter trees, lower tree density, and less coarse woody debris-conditions that may be promoted by fire-based management. Based on the TEK of Great Lakes tribes, [97] created a forest inventory field guide to identify the paper birch trees with preferred bark characteristics for traditional uses. A federal forest inventory implemented the guidelines and found that birch bark supply in the study area had declined.

In a national assessment of NTFPs in the U.S., [17] contended that including diverse harvesters in planning and management can be beneficial for long term sustainability. The NTFP species are frequently understudied: those who harvest them often hold detailed knowledge regarding species biology, phenology, ecological interactions, and response to harvest based on years of interactions. Including plant gatherer knowledge in management and monitoring efforts can provide important, current information on population health, observations of decline, and determinations of sustainable 
harvest limits (e.g., [29]). Studies have also found that integrating local knowledge into all steps of a participatory research design contributes to the refinement of methods that more accurately reflect the field conditions and experience-based interpretation of results [27]. In short, recommendations for sustainable NTFP management are more likely to be endorsed and practiced by harvesters when they participate in their formation $[98,99]$.

\subsection{Product Inventory}

Most foresters can inventory tree biomass with simple height and diameter measurements [90]. Repeating these measurements regularly allows for an estimation of stand growth and yield. With forest inventory data such as this, basic stand dimensions can be estimated for timber production, and they can support sound decisions that lead to sustainable management of the resources. This fundamental inventory data allows for the estimation of volumes of NTFPs that are related to tree production, particularly bark [100]. In cases where bark is harvested, the tree's bole surface area is of particular importance in determining a starting inventory. While using a truncated cone shape as an approximate representation of the tree's bole, [100] developed a regression model to estimate the surface area of slippery elm bark, a medicinal forest product. Although this approach is effective for the dozens of tree and shrub species that are valued for bark, alternate approaches are needed to inventory the other biological components that are harvested for non-timber forest products.

Taking inventory for most nontimber forest products is challenging, particularly when the desired product is belowground or when the product is ephemeral, lasting for a short time during the year. Models that are based on measurable plant parts and inventory methods that capture seasonal changes can serve as valuable tools for estimating available product quantities. As discussed in the case study of black cohosh, [80] developed a predictive model for below-ground biomass that is based on above-ground metrics. Evaluating measurements of plant height and canopy dimensions relative to rhizome weight for more than 1600 naturally occurring plants, the authors developed and validated a model that predicts the below-ground biomass at a stand level. However, comparable inventory methods are lacking for most of the NTFP categories. Preliminary inquiry with other NTFPs harvested for their roots show promise for inventory protocols, but much more complete analysis is needed.

\subsection{Harvest Considerations}

Managing forests for timber and nontimber products requires a consideration of harvest impacts on both resources, such as impacts of tree removal on understory plants and impacts of managing understory species on timber growth and production. Sustainable management for nontimber products may require changing the timing of timber harvests, as removing trees may create undue stress on understory species. Harvesting timber in the winter when understory plants are dormant allows more time for them to acclimate to changes in light and moisture regimes [89]. Likewise, the rotation length for trees may need to be longer to mitigate the impacts on nontimber species growing under the trees, or to promote NTFP species that prefer mature forest types. Chamberlain et al. [52] found that more ginseng was harvested in forest stands with more mature trees. In some cases, concurrent timber management may have a greater likelihood of success when the NTFPs have relatively long rotations between harvests.

Silvicultural treatments for nontimber products require the consideration of resource availability, particularly light, soil fertility, and moisture $[81,89,101]$. The seasonality of light availability is a key consideration for the production of NTFPs from understory plants that are associated with later successional stages and tolerate shade. Spring ephemeral forest herbs, such as ramps, require light early in the growing season during their photosynthesis stage. Later-emerging species, like black cohosh and ginseng, photosynthesize throughout the summer and thrive under canopies with high leaf area index $[8,68]$. Early successional and less shade-tolerant species, including many berry-producing shrubs, are found in open areas with full or partial sun, including forest edges and gaps. Still, others, such as hazelnuts (Corylus spp.), which are used for crafts (e.g., basketry) as well edible fruits, 
survive in shaded conditions, but they may require greater light to trigger flowering and subsequent fruit production.

Despite knowledge regarding site preferences and species response, long-term experimental harvest studies suggest that the growth responses may shift following disturbance [70]. Natural populations of black cohosh appear to be highly sensitive to resource availability, particularly light and soil fertility (Figure 4), making these important considerations for sustainable management. Unharvested Appalachian black cohosh populations, being monitored over a 10 to 14 years period, showed greater leaf area under higher tree canopy cover $(90 \%$ or greater canopy cover; Figure $4 \mathrm{~A})$ and soil fertility ( $\mathrm{pH}$, organic matter; Figure 4B-D). In contrast, black cohosh that was subjected to intense experimental harvest (66\% plant removal for three years) showed significantly less growth under deeply shaded conditions. After 6 to 10 years without additional harvest, the greatest recovery (increased leaf area) occurred on sites with higher light availability (75-85\% canopy cover; Figure $4 \mathrm{~A}$ ) and they were highly responsive to fertility, particularly higher soil $\mathrm{pH}$ (Figure 4B-D). Similar responses were observed for other growth metrics (e.g., stem density, plant height; not shown).
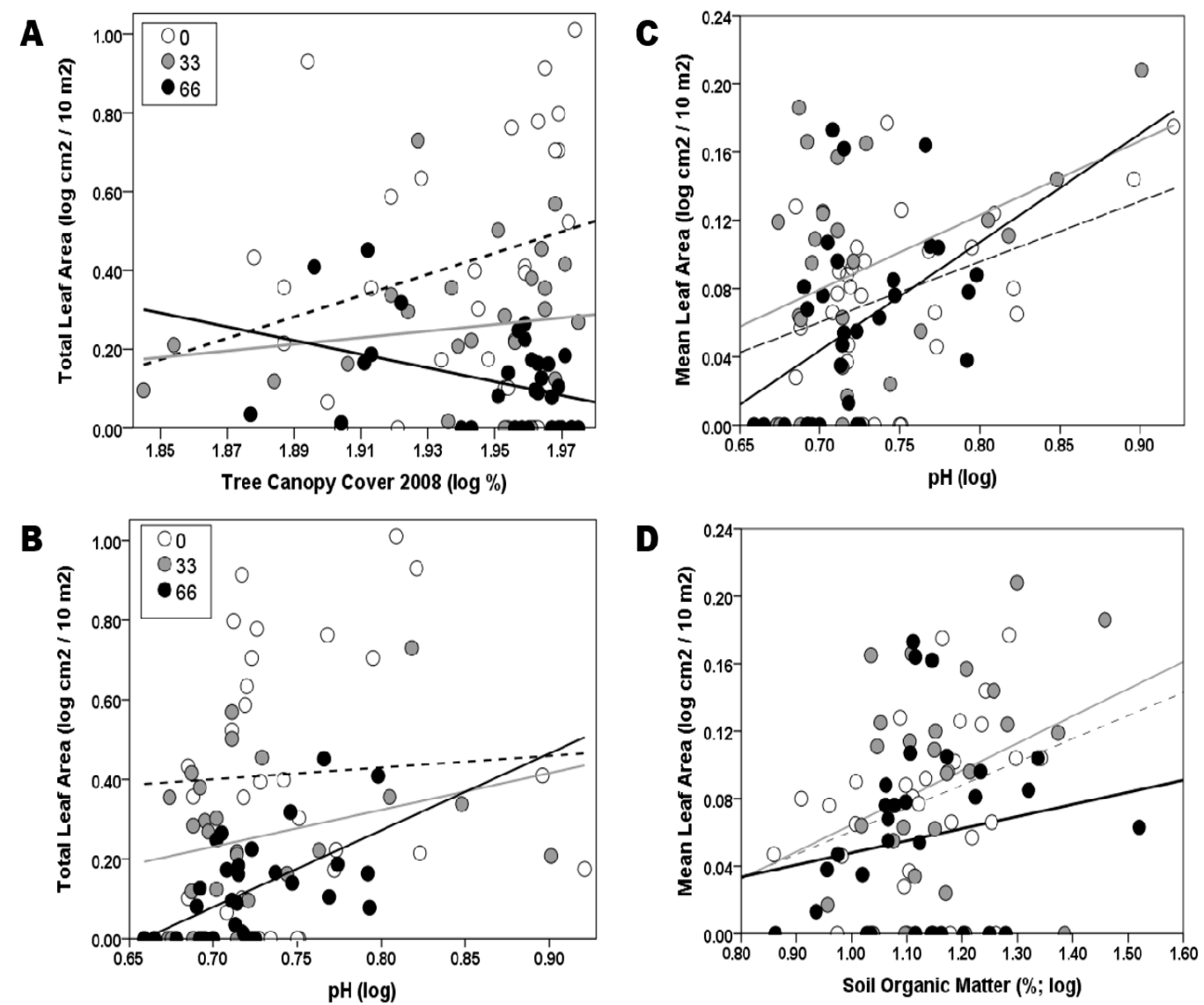

Figure 4. Relationship of above-ground growth of black cohosh relative to light and soil conditions in a Central Appalachian forest. Undisturbed populations ( $\%$ plant removal; open symbol, dashed line) responded favorably to increased tree canopy cover (A) and soil fertility measures (B-D). Populations subjected to intense experimental harvest (66\% plant removal) showed greatest "recovery" (six to 10 years without additional harvest) on sites with greater light availability (lower tree canopy cover; $r=-0.364, p=0.022$ ) and increased soil fertility (esp. $\mathrm{pH} ; r=-0.566, p=0.001$ ).

Despite knowledge regarding site preferences and species response, long-term experimental harvest studies suggest that the growth responses may shift following disturbance [70]. Natural populations of black cohosh appear to be highly sensitive to resource availability, particularly light and soil fertility (Figure 4), making these important considerations for sustainable management. 
Unharvested Appalachian black cohosh populations, being monitored over a 10 to 14 years period, showed greater leaf area under higher tree canopy cover (90\% or greater canopy cover; Figure $4 \mathrm{~A})$ and soil fertility ( $\mathrm{pH}$, organic matter; Figure 4B-D). In contrast, black cohosh that was subjected to intense experimental harvest (66\% plant removal for three years) showed significantly less growth under deeply shaded conditions. After 6 to 10 years without additional harvest, the greatest recovery (increased leaf area) occurred on sites with higher light availability (75-85\% canopy cover; Figure 4A) and they were highly responsive to fertility, particularly higher soil pH (Figure 4B-D). Similar responses were observed for other growth metrics (e.g., stem density, plant height; not shown).

The timing of harvest is an important consideration, as most NTFPs are harvested during specific times of the plant's life cycle. Understanding the seasonal changes to the plants and harvesting appropriately is important to the product's qualities. For example, the quality of paper birch bark that is used for various decorative items changes with the seasons [34,102,103]. Likewise, the quality and quantity of maple syrup change throughout the season. The roots of medicinal plants often are harvested after the above-ground vegetation has senesced, as it is believed that the medicinal properties are stronger. Szakiel et al. [104] emphasize the importance of environmental conditions, particularly light, temperature, fertility, and harvest season and methods, to the quality and quantity of secondary metabolites in wild harvested and cultivated medicinal plants, including American ginseng.

Isolating the effects of harvest on the other species and surrounding ecosystems are difficult, because the responses are based on complex and interacting factors, such as the severity of disturbance, site conditions and heterogeneity, and climate variability $[105,106])$. Forest management research examining the effects of silvicultural treatments on herbaceous and shrub layers rarely focus on the impacts on specific nontimber species. However, they do provide important information regarding understory responses in a variety of ecosystems and geographic locations that are known to be important habitats for NTFP species.

\subsection{Silvicultural Considerations for Nontimber Forest Products}

By modifying the silvicultural treatments, such as the amount of basal area removed, volume of trees retained, or targeting canopy strata to increase timber value of canopy trees, management approaches also can encourage nontimber products. Thinning treatments early in stand development can increase structural complexity [87] and opportunities for NTFP production. However, such gains may take time. Pilz et al. [107] found that chanterelle mushroom quantity and weight declined in the years immediately after thinning treatments, but productivity rebounded in six years, particularly in the lightly thinned stands. The impacts of thinning stands on NTFPs will vary with species, habitats, site quality, and intensity of silvicultural treatments, and addressing these potential effects is critical in successful management [66,108].

Likewise, silvicultural treatments that create gaps may increase the light availability and change soil moisture, temperature, and nutrient conditions. These conditions can negatively impact the shade-tolerant non-timber species $[101,105,109]$. Numerous studies have demonstrated that that late successional understory species, including black cohosh, bloodroot, and ramps, are eliminated or severely diminished after clearcut harvesting and they may require decades or more to recover $[66,108,109]$. These changes also tend to encourage aggressive, early-successional species, such as blackberries and raspberries (Rubus spp.) and non-native species that compete with desired understory herbs $[66,90]$. The site conditions for production of nontimber species are influenced by canopy gap size, orientation, and the amount of time that it takes to reduce the canopy. Additional research is needed to evaluate the impacts of silvicultural practices on nontimber forest species and the implications of integrating this knowledge into management practices.

\section{The Future for Nontimber Forest Products and Sustainable Forest Management}

Nontimber forest products, whether foods, medicines, crafts, or cultural products, contribute to the livelihoods of people worldwide. These values are expected to increase as human populations 
increase, with associated greater market demand for NTFPs. However, many of these valuable species are already threatened by overuse and associated ecological impacts, and the lack of management and market integration. Within the U.S., most NTFPs are neither tracked nor monitored, which limits the potential for economic gains and social benefits from these products. As the market demands for NTFPs increase, the species from which they originate are likely to face greater pressures. To ensure the long-term sustainability of these resources and the harvest of products, and to realize their economic potentials, much research and development is needed.

Integrating nontimber species into forest research and developing effective methods for inventory and monitoring is fundamental for their sustainable use, and for the health of forested ecosystems. Most studies on NTFPs have focused on harvest impacts or management at the population or species level, primarily on commercially important species. Although knowledge regarding the impacts that harvesting has on individual plants and populations is urgently needed to improve management, consideration, and attention of harvesting impacts at a broader ecological scales also is necessary. In addition, understanding the cultural importance and associated traditional and local knowledge regarding NTFPs is needed. In some cases, knowledge exists regarding how to harvest products with relatively little negative impact, but greater integration is needed to implement the appropriate and practical methods. Traditional and local ecological knowledge and management practices can provide fundamental information regarding the stewardship of NTFPs and the habitats and ecosystems in which they exist.

The future outlook for many nontimber species used as open access resources, such as American ginseng, is not promising. The examples presented are applicable to many other ecologically, economically, and socioculturally important NTFPs that are harvested for root-based products. Each species highlighted shows significant growth declines and population-level impacts, including a loss of genetic diversity, for years to decades after harvests. Comparable trends have been observed in other temperate medicinal herbs, such as goldenseal [12,71]. Limiting harvest intensities or frequencies is necessary to allow for these typically slow-growing populations significant time to recover. However, research is needed to determine the length of time that is needed for populations to recover, and this will differ by species. Even with such restrictions, research indicates that some populations may never return to the pre-harvest levels. Enhanced regeneration efforts may be necessary to replenish depleted populations, as what occurs with replanting trees after timber harvest.

Harvest issues discussed apply to the broader range of plant and fungal species used as nontimber products. The removal of plant parts, such as bark, can be physiologically stressful for the plant and they have been linked to water loss, reduced growth, vulnerability to pathogens, and overall plant decline [110]. Evidence suggests that native populations of some species may be in decline across their range due to harvest impacts. However, the relationships between harvest intensity and plant resilience remain poorly understood. As emphasized herein, effective inventory and assessment methods are needed for most commercially harvested NTFPs [111]. A better understanding of speciesand stand-level responses can be determined through focused research to promote the sustainable management of NTFPs [7]. We have the potential to mitigate the impacts on NTFPs and to use these products in perpetuity, without the loss of species or harm to surrounding ecosystems. An integral step in achieving a sustainable management of NTFPs is the recognition that they are renewable natural resources that require similar attention and management as other natural resources.

Author Contributions: J.C., C.S., and M.B. contributed equally on preparation of this manuscript. J.C. was invited to contribute on the subject. C.S. and M.B. were invited to contribute as coauthors because of their expertise in ecology, ethnobotany, and nontimber forest products.

Funding: This research received no external funding.

Conflicts of Interest: The authors declare no conflict of interest. 


\section{References}

1. Chamberlain, J.; Davis, J.; Duguid, M.; Ellum, D.; Farrell, M.; Friday, J.B.; Kruger, S.; Marcano-Vega, H.; McCoy, J.A.; Page, D.; et al. Nontimber Forest Products and Production. In Assessment of Nontimber Forest Products in the United States under Changing Conditions; General Technical Report SRS-232; Chamberlain, J.L., Emery, M., Patel-Weynand, T., Eds.; U.S. Department of Agriculture Forest Service, Southern Research Station: Asheville, NC, USA, 2018; Chapter 2; pp. 9-58, ISBN-13: 9780160945885.

2. Chamberlain, J.L.; Teets, A.; Kruger, S. Nontimber Forest Products in the United States: an Analysis for the 2015 National Sustainable Forest Report; e-General Technical Report SRS-229; U.S. Department of Agriculture Forest Service, Southern Research Station: Asheville, NC, USA, 2018; 42p.

3. Ticktin, T.; Shackleton, C. Harvesting nontimber forest products sustainably: Opportunities and challenges. In Nontimber Forest Products in the Global Context; Shackleton, S., Shackleton, C., Shanley, P., Eds.; Springer: Heidelberg, Germany, 2011; pp. 254-259, ISBN-13: 9783642179822.

4. Frey, G.E.; Chamberlain, J.L.; Prestemon, J.P. The potential for a backward-bending supply curve of non-timber forest products: An empirical study of wild American ginseng production. For. Policy Econ. 2018, 97, 97-109. [CrossRef]

5. Lake, F.K.; Emery, M.R.; Baumflek, M.J.; Friday, K.; Kamelamela, K.; Kruger, L.; Grewe, N.; Gilbert, J.; Reo, N. Cultural Dimensions of Non-timber Forest Products. In Assessment of Nontimber Forest Products in the United States under Changing Conditions; General Technical Report SRS-232; Chamberlain, J.L., Emery, M., Patel-Weynand, T., Eds.; U.S. Department of Agriculture Forest Service, Southern Research Station: Asheville, NC, USA, 2018; Chapter 4; pp. 83-100, ISBN-13: 9780160945885.

6. Chamberlain, J.; Bush, R.; Hammett, A.L. Nontimber forest products: the other forest products. For. Prod. J. 1998, 48, 10-20.

7. Chamberlain, J.L.; Emery, M.; Patel-Weynand, T. (Eds.) Assessment of Nontimber Forest Products in the United States under Changing Conditions; General Technical Report SRS-232; U.S. Department of Agriculture Forest Service, Southern Research Station: Asheville, NC, USA, 2018; 260p.

8. Muller, R.N. Nutrient relations of the herbaceous layer in deciduous forest ecosystems. In The Herbaceous Layer in Forests of Eastern North America; Gilliam, F.S., Roberts, M.R., Eds.; Oxford University Press: New York, NY, USA, 2003; pp. 15-37, ISBN-13: 9780160945885.

9. Gilliam, F.S. The ecological significance of the herbaceous layer in temperate forest ecosystems. BioScience 2007, 57, 845-858. [CrossRef]

10. Ticktin, T.; Kindscher, K.; Souther, S.; Weisberg, P.; Chamberlain, J.; Hummel, S.; Mitchell, C.; Sanders, S. Ecological Dimensions of Non-timber Forest Product Harvest. In Assessment of Nontimber Forest Products in the United States under Changing Conditions; General Technical Report SRS-232; Chamberlain, J.L., Emery, M., Patel-Weynand, T., Eds.; U.S. Department of Agriculture Forest Service, Southern Research Station: Asheville, NC, USA, 2018; Chapter 3; pp. 59-82, ISBN-13: 9780160945885.

11. Rock, J.H.; Beckage, B.; Gross, L.J. Population recovery following differential harvesting of Allium tricoccum Ait. in the southern Appalachians. Biol. Conserv. 2004, 116, 227-234. [CrossRef]

12. Albrecht, M.A.; McCarthy, B.C. Comparative analysis of goldenseal (Hydrastis canadensis L.) population re-growth following human harvest: Implications for conservation. Am. Midl. Nat. 2006, 156, $229-236$. [CrossRef]

13. Small, C.J.; Chamberlain, J.L.; Mathews, D.S. Recovery of black cohosh (Actaea racemosa L.) following experimental harvests. Am. Midl. Nat. 2011, 166, 339-348. [CrossRef]

14. McGraw, J.B.; Lubbers, A.E.; Van der Voort, M.; Mooney, E.H.; Furedi, M.A.; Souther, S.; Turner, J.B.; Chandler, J. Ecology and conservation of ginseng (Panax quinquefolius) in a changing world. Ann. N.Y. Acad. Sci. USA 2013, 1286, 62-91. [CrossRef]

15. Ticktin, T. The ecological sustainability of non-timber forest product harvest. In Ecological Sustainability for Non-timber Forest Products; Shackleton, C.M., Pandey, A.K., Ticktin, T., Eds.; Routledge Press: New York, NY, USA, 2015; Chapter 3; pp. 31-52, ISBN-13: 9780415728591.

16. Shackleton, C.M.; Ticktin, T.; Pandey, A.K. Introduction: The need to understand the ecological sustainability of non-timber forest products harvesting systems. In Ecological Sustainability for Non-timber Forest Products; Shackleton, C.M., Pandey, A.K., Ticktin, T., Eds.; Routledge Press: New York, NY, USA, 2015; pp. 3-11, ISBN-13: 9780415728591. 
17. Watson, K.; Christian, C.S.; Emery, M.R.; Hurley, P.T.; McLain, R.J.; Wilmsen, C. Chapter 5: Social dimensions of nontimber forest products. In Assessment of Nontimber Forest Products in the United States under Changing Conditions; General Technical Report SRS-232; Chamberlain, J.L., Emery, M., Patel-Weynand, T., Eds.; U.S. Department of Agriculture Forest Service, Southern Research Station: Asheville, NC, USA, 2018; Chapter 5; pp. 101-118, ISBN-13: 9780160945885.

18. Gianotti, A.G.S.; Hurley, P.T. Gathering plants and fungi along the urban-rural gradient: Uncovering differences in the attitudes and practices among urban, suburban, and rural landowners. Land Use Policy 2016, 57, 555-563. [CrossRef]

19. Robbins, P.; Emery, M.R.; Rice, J. Gathering in Thoreau's backyard: Nontimber forest product harvesting as practice. Area 2008, 40, 265-277. [CrossRef]

20. Butler, B.J.; Hewes, J.H.; Dickinson, B.J.; Andrejczyk, K.; Butler, S.M.; Markowski-Lindsay, M. USDA Forest Service National Woodland Owner Survey: national, regional, and state statistics for family forest and woodland ownerships with 10+ acres, 2011-2013; Resource Bulletin NRS-99; U.S. Department of Agriculture, Forest Service, Northern Research Station: Newtown Square, PA, USA, 2016; 39p.

21. Ginger, C.; Emery, M.R.; Baumflek, M.J.; Putnam, D.E. Access to natural resources on private property: Factors beyond right of entry. Soc. Nat. Resour. 2012, 25, 700-715. [CrossRef]

22. Emery, M.R.; Ginger, C.; Newman, S.; Giammusso, M.R.B. Special forest products in context: Gatherers and gathering in the Eastern United States; General Technical Report NE-306; U.S. Department of Agriculture, Forest Service, Northeastern Research Station: Newtown Square, PA, USA, 2003; 59p.

23. Garibaldi, A.; Turner, N. Cultural keystone species: Implications for ecological conservation and restoration. Ecol. Soc. 2004, 9, 1. [CrossRef]

24. Berkes, F. Sacred Ecology; Taylor and Francis: Philadelphia, PA, USA, 2008; ISBN-13: 9781138071490.

25. Berkes, F.; Colding, J.; Folke, C. Rediscovery of traditional ecological knowledge as adaptive management. Ecol. Appl. 2000, 10, 1251-1262. [CrossRef]

26. Davidson-Hunt, I.J.; Idrobo, C.J.; Pengelly, R.D.; Sylvester, O. Anishinaabe adaptation to environmental change in northwestern Ontario: A case study in knowledge coproduction for nontimber forest products. Ecol. Soc. 2013, 18. [CrossRef]

27. Ballard, H.L.; Huntsinger, L. Salal harvester local ecological knowledge, harvest practices and understory management on the Olympic Peninsula, Washington. Hum. Ecol. 2006, 34, 529-547. [CrossRef]

28. Emery, M.; Ginger, C.; Chamberlain, J. Migrants, markets and the transformation of natural resources management: Galax harvesting in western North Carolina. In Latinos in the New South-Transformations of Place; Smith, H.A., Furuseth, O.J., Eds.; Ashgate Publishing Company: Burlington, VT, USA, 2006; pp. 69-87, ISBN-13: 9780754644545.

29. Emery, M.R.; Barron, E.S. Using local ecological knowledge to assess morel decline in the US Mid-Atlantic region. Econ. Bot. 2010, 64, 205-216. [CrossRef]

30. Deur, D.; Turner, N.J. (Eds.) Keeping It Living: Traditions of Plant Use and Cultivation on the Northwest Coast of North America; University of Washington Press: Seattle, DC, USA, 2005; ISBN-13: 9780295985657.

31. Berkes, F.; Davidson-Hunt, I.J. Biodiversity, traditional management systems, and cultural landscapes: Examples from the boreal forest of Canada. Int. Soc. Sci. J. 2006, 58, 35-47. [CrossRef]

32. Kimmerer, R.W. Braiding Sweetgrass: Indigenous Wisdom, Scientific Knowledge and the Teachings of Plants; Milkweed Editions: Minneapolis, MN, USA, 2013; ISBN-13: 9781571313560.

33. Anderson, K. Tending the Wild: Native American Knowledge and the Management of California's Natural Resources; University of California Press: Berkeley, CA, USA, 2005; 588p, ISBN-13: 9780520280434.

34. Baumfek, M.J.; Emery, M.R.; Ginger, C. Culturally and Economically Important Nontimber Forest Products of Northern Maine; General Technical Report NRS-68; U.S. Department of Agriculture, Forest Service, Northern Research Station: Newtown Square, PA, USA, 2010; 74p.

35. Delcourt, H.R.; Delcourt, P.A. Pre-Columbian Native American Use of Fire on Southern Appalachian Landscapes. Conserv. Biol. 1997, 11, 1010-1014. [CrossRef]

36. Pretty, J.; Adams, B.; Berkes, F.; de Athayde, S.; Dudley, N.; Hunn, E.; Maffi, L.; Milton, K.; Raport, D.; Robbins, P.; et al. The intersections of biological diversity and cultural diversity: Towards integration. Conserv. Soc. 2009, 7, 100-112.

37. Gavin, M.C.; McCarter, J.; Mead, A.; Berkes, F.; Stepp, J.R.; Peterson, D.; Tang, R. Defining biocultural approaches to conservation. Trends Ecol. Evol. 2015, 30, 140-145. [CrossRef] 
38. Reid, L.A. The Effects of Traditional Harvesting Practices on Restored Sweetgrass Populations. Master's Thesis, State University of New York, College of Environmental Science and Forestry, Syracuse, NY, USA, 2005.

39. Hufford, M. Tending the commons: Folklife and landscape in southern West Virginia. In American Folklife Center; Library of Congress: Washington, DC, USA, 2000. Available online: https://www.loc.gov/collections/ folklife-and-landscape-in-southern-west-virginia/about-this-collection/ (accessed on 28 July 2018).

40. Baumflek, M.; Chamberlain, J.L. Ramps Reporting: What 70 Years of Popular Media Tells Us About A Cultural Keystone Species. Southeast. Geogr. 2019, 59, 77-96. [CrossRef]

41. Baumflek, M. Developing Standards for Sustainable Commercial Ramp Harvesting. Temp. Agrofor. 2016, 22. Available online: http://www.aftaweb.org/latest-newsletter/newsletter-test/listid-1/mailid-43-temperateagroforester-volume-22-number-3.html (accessed on 17 October 2018).

42. Nault, A.; Gagnon, D. Seasonal biomass and nutrient allocation patterns in wild leek (Allium tricoccum Ait.), a spring geophyte. B. Torrey Bot. Club 1988, 115, 45-54. [CrossRef]

43. Dion, P.P.; Bussières, J.; Lapointe, L. Late canopy closure delays senescence and promotes growth of the spring ephemeral wild leek (Allium tricoccum). Botany 2017, 95, 457-467. [CrossRef]

44. Nault, A.; Gagnon, D. Ramet demography of Allium tricoccum, a spring ephemeral, perennial forest herb. J. Ecol. 1993, 81, 101-119. [CrossRef]

45. Clabby, C. Mending a Native Food Web. North Carolina Health News. 10 October 2016. Available online: https://www.northcarolinahealthnews.org/2016/10/10/mending-a-native-food-web/ (accessed on 18 October 2018).

46. Dion, P.P.; Bussières, J.; Lapointe, L. Sustainable leaf harvesting and effects of plant density on wild leek cultivation plots and natural stands in Southern Quebec, Canada. Agrofor. Syst. 2016, 90, 979-995. [CrossRef]

47. Alexander, S.J.; Oswalt, S.N.; Emery, M.R. Non-Timber Forest Products in the United States: Montreal Process Indicators as Measures of Current Conditions and Sustainability; General Technical Report PNW-GTR-851; U.S. Department of Agriculture, Forest Service, Pacific Northwest Research Station: Portland, OR, USA, 2011; 36p.

48. Schlosser, W.; Blatner, K.; Chapman, R. Economic and marketing implications of special forest products harvest in the coastal Pacific Northwest. West. J. Appl. For. 1991, 6, 67-72.

49. Carrington, M.E.; Mullahey, J.J.; Krewer, G.; Boland, B.; Affolter, J. Saw palmetto (Serenoa repens): An emerging forest resource in the Southeastern United States. South. J. Appl. For. 2000, 24, 129-134.

50. American Herbal Products Association (AHPA). Tonnage Survey of Select North American Wild-Harvested Plants, 2006-2010; American Herbal Products Association: Silver Springs, MD, USA, 2012.

51. Frey, G.E.; Blatner, K.A.; Jacobson, M.G.; Starbuck Downes, C.M.; Sills, E.O.; Mercer, D.E.; Alexander, S.J.; Chamberlain, J.L.; Gold, M.A.; Godsey, L.D.; Emery, M.R.; Coffin, A.W.; Barlow, R.J.; Lohr, L. Economics of Non-timber Forest Products. In Assessment of Nontimber Forest Products in the United States under Changing Conditions; General Technical Report SRS-232; Chamberlain, J.L., Emery, M., Patel-Weynand, T., Eds.; U.S. Department of Agriculture Forest Service, Southern Research Station: Asheville, NC, USA, 2018; Chapter 6; pp. 119-150, ISBN-13: 9780160945885.

52. Chamberlain, J.L.; Prisley, S.; McGuffin, M. Understanding the relationship between American ginseng harvest and hardwood forests inventory and timber harvest to improve co-management of the forests of Eastern United States. J. Sustain. For. 2013, 32, 605-624. [CrossRef]

53. Taylor, D.A. Ginseng, the Divine Root: The Curious History of the Plant that Captivated the World; Algonquin Books: Chapel Hill, NC, USA, 2006; 308p, ISBN-13: 9781565124011.

54. Chandler, J.L.; McGraw, J.B. Variable effects of timber harvest on the survival, growth and reproduction of American ginseng (Panax quinquefolius L.). For. Ecol. Manag. 2015, 344, 1-9. [CrossRef]

55. Case, M.; Flinn, K.; Jancaitis, J.; Alley, A.; Paxton, A. Declining abundance of American ginseng (Panax quinquefolius L.) documented by herbarium specimens. Biol. Conserv. 2007, 134, 22-30. [CrossRef]

56. Cruse-Sanders, J.; Hamrick, J. Genetic diversity in harvested and protected populations of wild American ginseng, Panax quinquefolius L. (Araliaceae). Am. J. Bot. 2004, 91, 540-548. [CrossRef] [PubMed]

57. Schmidt, J.P.; Cruse-Sanders, J.; Chamberlain, J.L.; Ferreira, S.; Young, J.A. Explaining harvests of wild-harvested herbaceous plants: American ginseng as case study. Biol. Conserv. 2019, 321, 139-149. [CrossRef] 
58. Kruger, S.D. Measuring Medicinal Nontimber Forest Products Output in Eastern Deciduous Forests; Virginia Polytechnic Institute and State University: Blacksburg, VA, USA, 2018; 188p.

59. Copes, P. The backward-bending supply curve of the fishing industry. Scot. J. Polit. Econ. 1970, 17, 69-77. [CrossRef]

60. Gordon, H.S. The economic theory of a common-property resource: The fishery. J. Polit. Econ 1954, 62, 124-142. [CrossRef]

61. Hardin, G. The tragedy of the commons. Science 1968, 162, 1243-1248. [CrossRef]

62. Binkley, C.S. Long-run timber supply: Price elasticity, inventory elasticity, and the use of capital in timber production. Nat. Resour. Model 1993, 7, 163-181. [CrossRef]

63. Ticktin, T. The ecological consequences of harvesting nontimber forest products. J. Appl. Ecol. 2004, 41, 11-21. [CrossRef]

64. Greenfield, J.; Davis, J.M. Collection to Commerce: Western North Carolina Nontimber Forest Products and Their Markets; North Carolina State University: Raleigh, NC, USA, 2003. Available online: https://newcropsorganics. ces.ncsu.edu/wp-content/uploads/2016/11/ntfpfinal17.pdf?fwd=no. (accessed on 6 March 2019).

65. Frey, G.E.; Chamberlain, J.L. Collection of nontimber forest products from state forests in the US south. J. For. 2016, 114, 85-88. [CrossRef]

66. Small, C.J.; McCarthy, B.C. Spatial and temporal variation in the response of understory vegetation to disturbance in a central Appalachian oak forest. J. Torrey Bot. Soc. 2002, 129, 136-153. [CrossRef]

67. Chamberlain, J.L.; Small, C.J.; Baumflek, M. Sustainable Production of Temperate and Boreal Nontimber Forest Products: Examples from North America. In Achieving Sustainable Forestry; Volume 1, Boreal and Temperate Forests; Stanturf, J., Ed.; Burleigh Dodds Science Publishing: Cambridge, UK, (www.bdspublishing.com); 2019; (in press). ISBN 978-1-78676-292-4.

68. Whigham, D.F. Ecology of woodland herbs in temperate deciduous forests. Annu. Rev. Ecol. Syst. 2004, 35, 583-621. [CrossRef]

69. Mulligan, M.R.; Gorchov, D.L. Population loss of goldenseal, Hydrastis canadensis L. (Ranunculaceae), in Ohio. J. Torrey Bot. Soc. 2004, 131, 305-310. [CrossRef]

70. Small, C.J.; Chamberlain, J.L. Experimental harvest and regrowth in Appalachian black cohosh (Actaea racemosa, Ranunculaceae) populations: Implications for sustainable management of a medicinal forest herb. J. Torrey Bot. Soc. 2018, 145, 109-120. [CrossRef]

71. Van der Voort, M.; Bailey, B.; Samuel, D.E.; McGraw, J.B. Recovery of populations of goldenseal (Hydrastis canadensis L.) and American ginseng (Panax quinquefolius L.) following harvest. Am. Midl. Nat. 2003, 149, 282-292. [CrossRef]

72. Mooney, E.H.; McGraw, J.B. Relationship between age, size, and reproduction in populations of American ginseng, Panax quinquefolius (Araliaceae), across a range of harvest pressures. Ecoscience 2009, 16, 84-94. [CrossRef]

73. Castle, L.M.; Leopold, S.; Craft, R.; Kindscher, K. Ranking tool created for medicinal plants at risk of being overharvested in the wild. Ethnobiol. Lett. 2014, 5, 77-88. [CrossRef]

74. Aderkas, P.V.; Green, P.E.J. Leaf development of the ostrich fern Matteuccia struthiopteris (L.) Todaro. Bot. J. Linnean Soc. 1986, 93, 307-321. [CrossRef]

75. Bergeron, M.E.; Lapointe, L. Impact of one year crozier removal on long-term frond production in Matteuccia struthiopteris. Can. J. Plant Sci. 2001, 81, 155-163. [CrossRef]

76. Predny, M.L.; De Angelis, P.; Chamberlain, J.L. Black Cohosh (Actaea racemosa): An Annotated Bibliography; General Technical Report SRS-97; U.S. Department of Agriculture, Forest Service, Southern Research Station: Asheville, NC, USA, 2006; 99p.

77. NatureServe. Actaea racemosa L. NatureServe Explorer: An Online Encyclopedia of Life, Version 7.1; 2018. Available online: http://explorer.natureserve.org (accessed on 7 March 2019).

78. United Plant Savers. Species-at-Risk. 2018. Available online: http://www.unitedplantsavers.org/species-atrisk (accessed on 7 March 2019).

79. Piper, J.K. Distribution of dry mass between shoot and root in nine understory species. Am. Midl. Nat. 1989, 122, 114-119. [CrossRef]

80. Chamberlain, J.L.; Ness, G.; Small, C.J.; Bonner, S.J.; Hiebert, E.B. Modeling below-ground biomass to improve sustainable management of Actaea racemosa, a globally important medicinal forest product. For. Ecol. Manag. 2013, 293, 1-8. [CrossRef] 
81. Small, C.J.; Chamberlain, J.L.; Nuckols, C.M. Failure of black cohosh (Actaea racemosa L.) rhizome transplants: Potential causes and forest farming implications. Agrofor. Syst. 2014, 88, 815-822. [CrossRef]

82. Mudge, K.; Gabriel, S. Farming the Woods: An Integrated Permaculture Approach to Growing Food and Medicinals in Temperate Forests; Chelsea Green Publishing: White River Junction, VT, USA, 2014; 359p, ISBN-13: 9781603585071.

83. Chamberlain, J.L.; Mitchell, D.; Brigham, T.; Hobby, T.; Zabek, L.; Davis, J. Forest farming practices. In North American Agroforestry: An Integrated Science and Practice, 2nd ed.; Garrett, H.E., Ed.; American Society of Agronomy: Madison, WI, USA, 2009; Chapter 9; pp. 219-256, ISBN-13: 9780891181637.

84. Douglas, J.S.; De, J.; Hart, R.A. Forest Farming: Towards a Solution to Problems of World Hunger and Conservation; Intermediate Technology Publications: London, UK, 1976; 207p, ISBN-13: 9780946688302.

85. Munsell, J.; Davis, J.; Chamberlain, J. Forest farming. In Training Manual for Applied Agroforestry Practices; Gold, M., Cernusca, M., Hall, M., Eds.; University of Missouri, Center for Agroforestry: Columbia, MO, USA, 2013; pp. 115-126. Available online: http://www.centerforagroforestry.org/pubs/training/chap7_2015.pdf (accessed on 8 November 2019).

86. Thomas, A.L.; Crawford, R.J., Jr.; Havermann, L.J.; Applequist, W.L.; Schweitzer, B.E.; Woodbury, S.F.; Miller, J.S. Effect of planting depth, planting season, and fungicide treatment on establishment of black cohosh in a poorly drained soil. HortScience 2006, 41, 374-376. [CrossRef]

87. Hummel, S. Managing structural and compositional diversity with silviculture. In Compatible Forest Management; Monserud, R.A., Haynes, R.W., Johnson, A.C., Eds.; Kluwer Academic Publishers: Dordrecht, The Netherlands, 2003; Chapter 4; pp. 85-119, ISBN-13: 9781402015366.

88. Filotas, E.; Parrott, L.; Burton, P.L.; Chazdon, R.L.; Coates, K.D.; Coll, L.; Haeussler, S.; Martin, K.; Nocentini, S.; Puettmann, K.J.; et al. Viewing forests through the lens of complex systems. Ecosphere 2014, 5, 1-23. [CrossRef]

89. Ellum, D. Demographic Patterns and Disturbance Responses of Understory Vegetation in a Managed Forest of Southern New England: Implications for Sustainable Forestry and Biodiversity. Ph.D. Thesis, Yale University, New Haven, CT, USA, 2007; 235p.

90. Smith, D.M.; Larson, B.C.; Kelty, M.J.; Ashton, P.M.S. The Practice of Silviculture: Applied Forest Ecology; John Wiley and Sons: New York, NY, USA, 1997; 537p, ISBN-13: 9781119270959.

91. Trosper, R.L. Indigenous influence on forest management on the Menominee Indian Reservation. For. Ecol. Manag. 2007, 249, 134-139. [CrossRef]

92. Waller, D.M.; Reo, N.J. First Stewards: Ecological outcomes of forest and wildlife stewardship by Native peoples of Wisconsin, USA. BioScience 2018, 17, 18. [CrossRef]

93. Mockta, T.K.; Fulé, P.Z.; Meador, A.S.; Padilla, T.; Kim, Y.S. Sustainability of culturally important teepee poles on Mescalero Apache Tribal Lands: Characteristics and climate change effects. For. Ecol. Manag. 2018, 430, 250-258. [CrossRef]

94. Karuk Tribe of California. Department of Natural Resources, Eco-Cultural Resources Management Plan. 2010. Available online: http://www.karuk.us/images/docs/dnr/ECRMP_6-15-10_doc.pdf (accessed on 24 March 2019).

95. Forest Stewards. Forest Management Plan, Eastern Band of Cherokee Indian Trust Lands. 2016. Available online: https://cherokeenaturalresources.com/forestry-management/ (accessed on 24 March 2019).

96. Hummel, S.; Lake, F.K. Forest site classification for cultural plant harvest by tribal weavers can inform management. J. For. 2014, 113, 30-39. [CrossRef]

97. Emery, M.R.; Wrobel, A.; Hansen, M.H.; Dockry, M.; Moser, W.K.; Stark, K.J.; Gilbert, J.H. Using traditional ecological knowledge as a basis for targeted forest inventories: Paper birch (Betula papyrifera) in the US Great Lakes region. J. For. 2014, 112, 207-214. [CrossRef]

98. Charnley, S.; Fischer, A.P.; Jones, E.T. Integrating traditional and local ecological knowledge into forest biodiversity conservation in the Pacific Northwest. For. Ecol. Manag. 2007, 246, 14-28. [CrossRef]

99. Fortmann, L.; Ballard, H. Sciences, knowledges, and the practice of forestry. Eur. J. For. Res. 2011, 130, 467-477. [CrossRef]

100. Kauffman, J.S.; Prisley, S.P.; Chamberlain, J.L. Monitoring nontimber forest products using forest inventory data: An example with slippery elm bark. J. For. 2015, 114, 1-8. [CrossRef]

101. Duguid, M.C.; Frey, B.R.; Ellum, D.S.; Kelty, M.; Ashton, M.S. The influence of ground disturbance and gap position on understory plant diversity in upland forests of southern New England. For. Ecol. Manag. 2013, 303, 148-159. [CrossRef] 
102. Stewart, H. Cedar: Tree of Life to the Northwest Coast Indians; University of Washington Press: Washington, DC, USA, 1995; 192p, ISBN-13: 9780295974484.

103. Emery, M.R.; Zasada, J. Silviculture and nontimber forest products: Extending the benefits of forest management. The Timberline 2001, 10-13. Available online: https://www.fs.usda.gov/treesearch/pubs/18991 (accessed on 24 March 2019).

104. Szakiel, A.; Paczkowski, C.; Henry, M. Influence of environmental abiotic factors on the content of saponins in plants. Phytochem. Rev. 2011, 10, 471-491. [CrossRef]

105. Small, C.J.; McCarthy, B.C. Relationship of understory diversity to soil nitrogen, topographic variation, and stand age in an eastern oak forest, USA. For. Ecol. Manag. 2005, 217, 229-243. [CrossRef]

106. Elliott, K.J.; Vose, J.M.; Rankin, D. Herbaceous species composition and richness of mesophytic cove forests in the southern Appalachians: Synthesis and knowledge gaps. J. Torrey Bot. 2014, 141, 39-71. [CrossRef]

107. Pilz, D.; Molina, R.; Mayo, J. Effects of thinning young forests on chanterelle mushroom production. J. For. 2006, 104, 9-14. [CrossRef]

108. Elliott, K.J.; Boring, L.R.; Swank, W.T.; Haines, B.R. Successional changes in plant species diversity and composition after clearcutting a southern Appalachian watershed. For. Ecol. Manag. 1997, 92, 67-85. [CrossRef]

109. Meier, A.J.; Bratton, S.; Duffy, D. Possible ecological mechanisms for loss of vernal-herb diversity in logged eastern deciduous forests. Ecol. Appl. 1995, 5, 935-946. [CrossRef]

110. Costa, A.; Nunes, L.C.; Spiecker, H.; Graça, J. Insights into the responsiveness of cork oak (Quercus suber L.) to bark harvesting. Econ. Bot. 2015, 69, 171-184. [CrossRef]

111. Vaughan, R.C.; Munsell, J.F.; Chamberlain, J.L. Opportunities for Enhancing Nontimber Forest Products Management in the United States. J. For. 2013, 111, 26-33. [CrossRef]

(C) 2019 by the authors. Licensee MDPI, Basel, Switzerland. This article is an open access article distributed under the terms and conditions of the Creative Commons Attribution (CC BY) license (http://creativecommons.org/licenses/by/4.0/). 